\title{
Journal of Health Sciences
}

\section{Quality of life of mothers who have children with developmental disabilities}

\author{
Jasmina Mahmutović1* , Najda Veladžić1, Amra Mačak Hadžiomerović1, \\ Suada Branković ${ }^{1}$, Hadžan Konjo', Đemil Omerović
}

${ }^{1}$ Faculty of Health Studies, University of Sarajevo, Sarajevo, Bosnia and Herzegovina, ${ }^{2}$ Orthopedics and Traumatology Clinic, University Clinical Center SARAJEVO, Sarajevo, Bosnia and Herzegovina

\begin{abstract}
Introduction: The primary source of strength and support is the child's family. A special role in caring for a child with developmental disabilities is played by his mother. The objective of this research is to find out the assessment of the quality of life (QOL) of disabled children mothers as well as to research the relation of sociodemographic variables of the respondents, as specified in this study and estimate the quality of their life and health.
\end{abstract}

Methods: The cross-sectional study was performed by the use of the descriptive-analytical method. In a targeted association of families which have children and persons with difficulties was conducted this research on a sample of 100 registered mothers. The research instrument was the standardized questionnaire for QOL, the World Health Organization QOL-BREF and the users' records of the mothers in the association.

Results: The average age of the respondents was $M=48.01 \pm 11.68$. About $62 \%$ of the respondents are married, $54 \%$ have a high school diploma, $67 \%$ are not employed, $68 \%$ of the respondents did not declare to have health problems, and among those who declared to have health problems, the most common disease was diabetes mellitus. The average number of household members was $M=3.44$ members. The number of the household members was significantly and positively related to the domain of social interaction ( $r s=0.219 ; p<0.05)$, the domain of the environment $(r s=0.220 ; p<0.05)$ and to the general QOL ( $r s=0.227 ; p<0.05)$. The age of the respondents was significantly and positively related only to the environmental domain ( $r s=0.205 ; p<0.05)$. The respondents who drive a car showed a significantly higher level of QOL in the field of mental health $(p=0.042)$ and the environment $(p=0$. 005). Concerning mothers with higher incomes rate, their QOL was better in the following domains: Physical health $(p=0.030)$, mental health $(p=0.002)$, environment $(p=0.000001)$, and general QOL ( $p=0.0002)$.

Conclusion: The respondents with a larger number of household members, those who have the support of family members, who were without health problems, and who independently use own car for transportation, consider their QOL as being better. Therefore, a promotional - preventive program for improving the life quality of mothers of children and persons with disabilities should include accessible life in the community and the

Corresponding author: Jasmina Mahmutović, Faculty of Health Studies, University of Sarajevo, Sarajevo, Bosnia and Herzegovina.

E-mail: jasmina,mahmutovic@fzs.unsa.ba

Submitted: 26 May 2020/Accepted: 29 September 2020 ability to recognize the unique needs of the entire family of children and persons with disabilities.

Keywords: QOL; WHOQOL-BREF; Developmental disabilities 


\section{INTRODUCTION}

A child with developmental disabilities affects family dynamics and relationships between family members. Changes in the family that may occur over time may result in the child's uncertain health status as well as increased responsibilities placed on family members (1). Families that function well and have significant quality of life (QOL) were seen as a social resource for the child (2).

Parents of children and persons with disabilities go through a series of inconveniences and adjustments in the course of efforts to provide their child with conditions for a normal life (3). Often the lives of these families will be changed fundamentally and adapted to their child' needs. This change is first of all reflected in the adaptation of living spaces and the environment to the lives of children or persons with disabilities, allocating a significant amount of money for medical and rehabilitation treatment, orthopedic aids, and the like (4).

The American Academy of Paediatrics emphasizes that the family is the child's primary source of strength and support, that is, that the role of the family in caring for the child is very important, especially the role of the mother (5).

Swedish authors in their research concluded that mothers, but not fathers, have a poorer perception of health-related QOL (6).

Rodrigues et al. (2018), in a study conducted in Brazil, pointed out that the care of children with developmental disabilities is focused on the mother (7). Long-term health care for children with complex conditions can be difficult and can adversely affect the mother's psychological state (8). Mothers of children with disabilities have a higher risk of mental illness (9). The impact of stress on the mother has a negative effect, but also on the psychological health of other family members (10).

The lives of mothers of children and persons with disabilities are not different from the lives of other mothers, but many of them are lonely and the vast majority of them never get a job opportunity (11).

When the mother of a child with developmental disabilities gets the opportunity to work, she becomes independent, which significantly affects the quality of her life, and also increases self-confidence (12).
Glinac et al. (2017), in a study in Tuzla Canton, confirmed also that mothers of children with cerebral palsy had a poorer valuation of their QOL in all measured domains (13).

Emphasizing the quality of family life emerges from recognizing the very important role of the family in maintaining functional and lasting stability in every human life. Families that function well and have a significant QOL are seen as a social resource. Hence, these families should be given special consideration in determining the degree to which they are able to enjoy a significant and satisfactory QOL (14).

Health-care professionals are often the first people with whom the child and family establish contact and represent a source of important information, support, and care, and it is necessary to work on programs to improve the effectiveness of preventive health care because it can contribute to improving the quality of health and health care of children's family and people with developmental disabilities $(15,16)$.

The aim of the research is to determine the assessment of the QOL of mothers of children with disabilities and to examine the relationship between the sociodemographic variables of the respondents and the assessment of the quality of their life and health.

\section{METHODS}

A cross-sectional study was performed by the use of a descriptive-analytical method. During 2019, in the association of families of children and persons with disabilities "Give us a Chance" in Sarajevo Canton, a survey was conducted on a sample of 100 registered mothers of children and persons with disabilities. Registered mothers voluntarily agreed to the research and gave written consent. The research was conducted during the period from May to September 2019. Respondents completed the questionnaire in the presence of the examiner, with individual completion of the questionnaire taking an average of $30 \mathrm{~min}$. Based on the approved consent for the collection and use of data from the beneficiary of the association "Give us a Chance" by the director of the association, the research part of the work was started. 
The research instrument is a standardized questionnaire on the QOL of the World Health Organization (World Health Organization QOL [WHOQOL] BREF) $(17,18)$ and the users' cards of the association's mothers.

The WHOQOL - BREF questionnaire consists of 26 questions, and each question is scored on a Likert scale from 1 (worst) to 5 (best). Using this questionnaire was scores separately the perception of QOL in each of the four fields of the questionnaire (physical health, mental health, social interaction, and environment), where the scale is positive, which means that more points represent a higher QOL (19-21).

The SPSS 22.0 software package was used for statistical analysis of the obtained data. Based on the results of the Kolmogorov-Smirnov test, were used appropriate nonparametric tests, Spearman's Rho test for correlation testing, and Mann-Whitney U test for analysis of differences between groups as well as Kruskal-Wallis test for analysis of differences between several groups.

\section{RESULTS}

The total sample consisted of 100 respondents aged 20-80 years. The average age of the subjects was $\mathrm{M}=48.01 \pm 11.68$. The average number of household members is $\mathrm{M}=3.44$ members, and within the household, the average number of children/ persons with disabilities is $M=1.04$. The largest percentage $(62 \%)$ of respondents is married, $54 \%$ have a high school diploma, and $67 \%$ of them are not employed. According to the respondents' statements, $68 \%$ of them declared they did not have any health problems, and among those who reported health problems, diabetes mellitus was the most common disease. Regarding the support of other household members in caring for the children or persons with disabilities, $68 \%$ of the respondents stated that they had the support of the other household members, while $32 \%$ of them had no support from household members.

From the medical documentation of children and users of the association "Give us a Chance," it was determined that $64 \%$ of children with disabilities have one established diagnosis, $27 \%$ have two diagnoses, while $9 \%$ have three diagnoses. The most frequently verified diagnoses of users are cerebral palsy $(28 \%)$, autism (16\%), epilepsy (12\%), and mild mental retardation (11\%), but the total number of verified diagnoses was even 40 different diagnoses.

The research instrument was subjected to a test of the reliability of the internal consistency and showed with the value of Cronbach's $\alpha$ coefficient which amounted a total 0.95 .

Table 1. shows the results for the WHOQOLBREF questionnaire, showing the values of the four main domains measured by the questionnaire. As can be seen from the table, the results range from 0 to 100 , except in the domain of environment where the lowest recorded result is 6 . The highest subjective assessment of QOL have respondents in domain of mental health $(M=64.07 \pm 23.41)$ and physical health $(\mathrm{M}=63.71 \pm 22.10)$. The lowest result was measured for the domain of social interaction $(\mathrm{M}=54.20 \pm 26.40)$. The WHOQOL-BREF questionnaire have two questions that represent a subjective assessment of quality of life and health, which do not apply to any of the previously mentioned domains, where grade one being the worst grade and grade five being the best grade for assessing overall quality of life and overall satisfaction.

To determine the impact of individual variables on the perception of the QOL and health of the respondents, certain sociodemographic variables were analyzed.

In the Table 2., Spearman's rho rate showed that the number of household members was significantly and positively related to the domain of social interaction ( $\mathrm{rs}=0.219 ; p<0.05$ ) to the domain of the environment ( $\mathrm{rs}=0.220 ; p<0.05)$ and to the general QOL ( $\mathrm{rs}=227$; $p<0.05$ ). Respondents from families with a larger number of household members have higher results in the field of social interaction, environment, as well as in the question of assessing the general QOL. The age of the respondents is significantly and positively related only to the environmental domain ( $\mathrm{rs}=0.205 ; p<0.05$ ), that is, older respondents showed greater satisfaction with the quality of the environment.

As can be seen from the Table 3., the Mann-Whitney test showed that the respondents who drive a car showed a significantly higher level of QOL in the 
TABLE 1. Quality of live assessment of mothers

\begin{tabular}{lcccccccc}
\hline Domain & $\mathrm{N}$ & Min & Max & 25. percentile & Median & 75. percentile & M & SD \\
\hline Physical health & 100 & 0 & 100 & 44 & 69 & 81 & 63,71 & 22,10 \\
Mental health & 100 & 0 & 100 & 50 & 63 & 88 & 64,07 & 23,41 \\
Social interaction & 100 & 0 & 100 & 31 & 50 & 75 & 54,20 & 26,40 \\
Environment & 100 & 6 & 100 & 38 & 56 & 73 & 56,52 & 21,81 \\
General quality of life & 100 & 1 & 5 & 3 & 3 & 4 & 3,24 & 0,99 \\
General health satisfaction & 100 & 1 & 5 & 3 & 4 & 4 & 3,33 & 1,06 \\
\hline
\end{tabular}

TABLE 2. Correlations among the number of diagnoses, household members, and age with the results based on WHOQOL-BREF

\begin{tabular}{lcccccccc}
\hline & $\begin{array}{c}\text { No. of } \\
\text { household } \\
\text { members }\end{array}$ & Dob & $\begin{array}{c}\text { physical } \\
\text { health }\end{array}$ & $\begin{array}{c}\text { Mental } \\
\text { health }\end{array}$ & $\begin{array}{c}\text { Social } \\
\text { interaction }\end{array}$ & Environment & $\begin{array}{c}\text { Prevailing } \\
\text { quality of life }\end{array}$ & $\begin{array}{c}\text { Prevalent health } \\
\text { satisfaction }\end{array}$ \\
\hline $\begin{array}{l}\text { No. of diagnosis } \\
\text { No. of household }\end{array}$ & 0.075 & 0.071 & -0.039 & 0.080 & 0.054 & 0.117 & 0.179 & 0.089 \\
members & & $-0.257^{* *}$ & 0.088 & 0.098 & $0.219^{*}$ & $0.220^{*}$ & $0.227^{*}$ & 0.127 \\
Age & & & 0.196 & 0.184 & 0.114 & $0.205^{*}$ & 0.094 & 0.101 \\
Physical health & & & & $0.828^{* *}$ & $0.627^{* *}$ & $0.696^{* *}$ & $0.639^{* *}$ & $0.730^{* *}$ \\
Mental health & & & & $0.765^{* *}$ & $0.763^{* *}$ & $0.716^{* *}$ & $0.713^{* *}$ \\
Social interaction & & & & & $0.652^{* *}$ & $0.510^{* *}$ & $0.511^{* *}$ \\
$\begin{array}{l}\text { Environment } \\
\text { General quality of life }\end{array}$ & & & & & & $0.718^{* *}$ & $0.608^{* *}$ \\
\hline
\end{tabular}

${ }^{*}-p<0.05 ;{ }^{* *}-p<0.01$

TABLE 3. Correlation between quality of life and respondents who are driver

\begin{tabular}{llllllll}
\hline Domain & Group & $\mathrm{N}$ & $\mathrm{M}$ & $\mathrm{SD}$ & $\mathrm{M}$ rank & $\mathrm{U}$ & $\mathrm{P}$ \\
\hline Physical health & Drivers & 36 & 68,42 & 19,60 & 56,24 & 945,50 & 0,136 \\
\multirow{3}{*}{ Mental health } & Non-drivers & 64 & 61,06 & 23,12 & 47,27 & & \\
& Drivers & 36 & 70,50 & 21,54 & 58,33 & 870,00 & $\mathbf{0 , 0 4 2}$ \\
Social interaction & Non-drivers & 64 & 60,45 & 23,79 & 46,09 & & \\
\multirow{5}{*}{ Environment } & Drivers & 36 & 59,92 & 22,83 & 56,26 & 944,50 & 0,134 \\
& Non-drivers & 64 & 50,98 & 27,86 & 47,26 & & \\
General quality of life & Drivers & 36 & 64,11 & 23,09 & 61,31 & 763,00 & $\mathbf{0 , 0 0 5}$ \\
& Non-drivers & 64 & 52,25 & 19,99 & 44,42 & & \\
General health satisfaction & Drivers & 36 & 3,56 & 0,91 & 58,75 & 855,00 & $\mathbf{0 , 0 2 4}$ \\
& Non-drivers & 64 & 3,06 & 0,99 & 45,86 & & \\
& Drivers & 36 & 3,67 & 0,83 & 58,61 & 860 & $\mathbf{0 . 2 6}$ \\
& Non-drivers & 64 & 3,14 & 1,14 & 45,94 & & \\
\hline
\end{tabular}

domain of mental health $(p=0.042)$ and the environment $(p=0.005)$. In the other two domains, the female respondents, being drivers, performed better results. However, the difference between them was not statistically significant. Significant differences are also noticeable in the question of general QOL $(p=0.024)$ and health satisfaction (0.026).

Results in Table 4. showed that mothers who have the support of household members rate their QOL better in each of the four domains of health compared 
to mothers who do not have support of household members. The differences are also significant on issues of general QOL satisfaction and health satisfaction.

As can be seen from the Table 5., respondents who stated that they currently have health problems achieved worse results on the questionnaire than respondents who did not have health problems. Respodents who do not have health problems show higher results on all scales, and statistically significantly higher results of healthy people in the field of physical health $(\mathrm{U}=705, \mathrm{p}<0.01)$, mental health (U $=739.5, \mathrm{p}<0.05)$, satisfaction with social interactions $(\mathrm{U}=809.5, \mathrm{p}<0.05)$, as well as in the domain of environmental satisfaction $(U=823, \mathrm{p}<0.05)$.

\section{DISCUSSION}

Families of children with intellectual and developmental disabilities endure a high degree of psychological and social difficulties (22).

TABLE 4. Support of household members and quality of life of mothers

\begin{tabular}{|c|c|c|c|c|c|c|c|}
\hline Domain & Support of household members & $\mathrm{N}$ & $\mathrm{M}$ & SD & M rank & $U$ & $P$ \\
\hline \multirow[t]{2}{*}{ Physical health } & Yes & 68 & 68,19 & 21,05 & 56,63 & 671,00 & 0,002 \\
\hline & No & 32 & 54,19 & 21,55 & 37,47 & & \\
\hline \multirow[t]{2}{*}{ Mental health } & Yes & 68 & 68,53 & 23,83 & 56,73 & 664,50 & 0,002 \\
\hline & No & 32 & 54,59 & 19,64 & 37,27 & & \\
\hline \multirow[t]{2}{*}{ Social interaction } & Yes & 68 & 60,94 & 25,15 & 57,99 & 578,50 & 0,0002 \\
\hline & No & 32 & 39,88 & 23,39 & 34,58 & & \\
\hline \multirow[t]{2}{*}{ Environment } & Yes & 68 & 62,44 & 20,80 & 58,60 & 537,00 & 0,00004 \\
\hline & No & 32 & 43,94 & 18,54 & 33,28 & & \\
\hline \multirow[t]{2}{*}{ General quality of life } & Yes & 68 & 3,46 & 1,00 & 56,83 & 657,50 & 0,001 \\
\hline & No & 32 & 2,78 & 0,79 & 37,05 & & \\
\hline \multirow[t]{2}{*}{ General health satisfaction } & Yes & 68 & 3,53 & 1,01 & 55,72 & 733,00 & 0,005 \\
\hline & No & 32 & 2,91 & 1,06 & 39,41 & & \\
\hline
\end{tabular}

Mann-Whitney U test

TABLE 5. Quality of life of mothers in relation to the presence of a health problem

\begin{tabular}{lllllllc}
\hline Domain & Group & $\mathrm{N}$ & $\mathrm{M}$ & $\mathrm{SD}$ & $\mathrm{M}$ rank & $\mathrm{U}$ & $\mathrm{P}$ \\
\hline Physical health & Sick & 32 & 53,31 & 25,42 & 38,53 & 705,00 & $\mathbf{0 , 0 0 4}$ \\
Mental health & Healthy & 68 & 68,60 & 18,63 & 56,13 & & \\
& Sick & 32 & 54,00 & 27,44 & 39,61 & 739,50 & $\mathbf{0 , 0 1 0}$ \\
Social interaction & Healthy & 68 & 68,81 & 19,74 & 55,63 & & \\
\multirow{3}{*}{ Environment } & Sick & 32 & 46,72 & 28,76 & 41,80 & 809,50 & $\mathbf{0 , 0 3 9}$ \\
& Healthy & 68 & 57,72 & 24,65 & 54,60 & & \\
General quality of life & Sick & 32 & 50,88 & 23,02 & 42,22 & 823,00 & $\mathbf{0 , 0 4 9}$ \\
& Healthy & 68 & 59,18 & 20,86 & 54,40 & & \\
General health satisfaction & Sick & 32 & 2,66 & 1,04 & 34,08 & 562,50 & $\mathbf{0 , 0 0 0 0 4}$ \\
& Healthy & 68 & 3,51 & 0,84 & 58,23 & & \\
& Sick & 32 & 2,63 & 1,10 & 32,39 & 508,50 & $\mathbf{0 , 0 0 0 0 1}$
\end{tabular}

Mann-Whitney U test 
The results of other researches show that family adjustment varies according to the type and degree of disability. Studies of families with children with Down syndrome have shown a lower level of stress than families with children with autism or developmental disability of unknown cause. These differences may be due to the child's temperament, social responses and behavior, and the availability of support services, especially in early childhood (23).

A large number of verified diagnoses cause specific stress for the users of the association Give us a Chance and impose special requirements on the family, because both the family and the child have to adapt themselves to a number of unwanted and unpleasant circumstances, and they also endure significant changes over time.

The results of this study were compared to the results of a study by Hawthorn et al. (2006) in which the authors presented reference values for WHOQOLBREF for the general population. By comparing the results of this study with the reference values from the study of Hawthorne et al., it can be seen that the assessment of the QOL of mothers of the association "Give us a chance" is lower in all domains, especially in the domains of social interaction and the environment (24).

The same results were confirmed during 2017 by Wu et al. conducting research in China, using SF 36 questionnaires to assess the QOL of mothers of children with cerebral palsy (25).

Lee et al. (2019), in their study, obtained a very poor value in QOL of mothers of children with cerebral palsy (26).

Our research also confirmed that mothers who currently have health problems have significantly lower scores in all areas of health than mothers who do not have health problems.

The biggest obstacle in the interpretation of QOL measuring is the lack of a "gold standard" or a unit of measurement that would allow comparison of QOL among different populations, regions, and over different periods (27).

Caring for children with disabilities is a greater burden on older mothers, which has a negative impact on the assessment of their QOL (28). In our study, we did not find a correlation between QOL and age, except that there is a positive and weak correlation (rho $=0.20)$ of older mothers and the environmental domain.

Mothers who drive a car show a significantly higher level of satisfaction in all domains except in the domain of social interaction. It is likely that mothers who drive feel greater freedom and a degree of independence in life compared to those mothers who do not drive a car, which leads to greater satisfaction in certain domains.

The importance of the support of household members in the increase of QOL of mothers caring for children with disabilities is also confirmed by the research in Flanders in Belgium. Emphasized is the need for greater support (e.g., rest cure and babysitting) which does not have to be the support of professionals, but support within the family in everyday life (29).

Adaptation to a child with intellectual or developmental disabilities is extremely important because it affects not only the overall psychophysical development of the child but also the overall psychophysical status and QOL of its mother. Caring for children is dynamic and mothers spend energy due to longterm chronic problems related to the condition or disability. It is necessary to look for programs to monitor the health of mothers and families of children with disabilities, and to improve the effectiveness of preventive health care.

Kuru and Piyal (2018) point out that health professional should be focused on determining the needs of families according to which they will plan and implement programs (30).

The support system for people with intellectual disabilities in Bosnia and Herzegovina is still not in line with the Convention on the Rights of Persons with Disabilities because the conditions and system support for people with disabilities have not been created, especially when making informed decisions on all issues and rights regarding them (31).

Based on the results of the research, additional research is needed to assess how preventive health services can contribute to the improvement of the health and QOL of registered mothers in the association of families of children and persons with disabilities "Give us a Chance." 


\section{CONCLUSION}

Certain sociodemographic variables affect the subjective assessment of the QOL of mothers who have children with disabilities. Respondents, with a larger number of household members and have the support of family members, without own health problems and who independently use a personal car for the purpose of transportation, estimate as higher their QOL. Guidelines for health professionals to improve the QOL of mothers of children and persons with disabilities should include assessing the physical and psychological health of parents and their functioning, focusing on their basic health needs and providing interventions to improve family health and establishing support services to help children's family and people with disabilities having professional support in meeting their specific needs.

\section{REFERENCES}

1. Švraka E, Avdić D. Naša Vizija Budućnosti: Inkluzija Osoba s Cerebralnom Paralizom i Inaktivitetna Osteoporoza. Sarajevo: Savez Udruženja Osoba s Cerebralnom Paralizom FBiH; 2015. p. 59-64.

2. Cvitković $D$, Ralić $A Z$, Jakab AW. Vrijednosti, interakcija sa zajednicom i kvaliteta života obitelji djece s teškoćama u razvoju. Hrvatska Rev Rehabil Istraživanja 2013;49:10-22.

3. Švraka E, Šego I. Kućna Fizikalna Terapija Djece s Poteškoćama u Učenju. Sarajevo: Centar Vladimir Nazor; 2007. Available from: https://www. cpafbih.org/wp-content/uploads/2017/12/Prirucnik-za-roditelje.pdf. [Last accessed on 2019 May 03].

4. Švraka E, Salkić N. Računa se Sposobnost, a ne Onesposobljenje: Sport i Unapređenje Kvaliteta Života s Cerebralnom Paralizom i Djece s Oštećenjem Sluha i Govora i Njihovih Obitelji. Sarajevo: Savez Udruženja Osoba s Cerebralnom Paralizom FBiH; 2016. p. 126-30.

https://doi.org/10.7251/sceped1802001s.

5. Benjak T. Kvaliteta Života i Zdravlje Roditelja Djece s Pervazivnim Razvojnim Poremećajem. Doktorska Disertacija. Zagreb: Sveučilište u Zagrebu; 2010.

6. Allik H, Larsson JO, Smedje H. Health-related quality of life in parents of school-age children with Asperger syndrome or high-functioning autism. Health Qual Life Outcomes 2006;4:1

https://doi.org/10.1007/978-0-387-78665-0_210.

7. Rodrigues SA, Fontanella BJ, de Avó LR, Germano CM, Melo DG. A qualitative stud about quality of life in Brazilian families with children who have severe or profound intellectual disability. J Appl Res Intellect Disabil 2019;32(2):413-26.

https://doi.org/10.1111/jar.12539.

8. Ware JE Jr., Sherbourne CD. The MOS 36-item short-form health survey (SF-36), I. Conceptual framework and item selection. Med Care 1992;30(6):473-83.

https://doi.org/10.1097/00005650-199206000-00002.

9. Gilson KM, Johnson S, Davis E, Brunton S, Swift E, Reddihough D, et al. Supporting the mental health of mothers of children with a disability: Health professional perceptions of need, role, and challenges. Child Care Health Dev 2018;44(5):721-9.

https://doi.org/10.1111/cch.12589.
10. Hastings RP. Child behaviour problems and partner mental health as correlates of stress sin mothers and fathers of children with autism. J Intellect Disabil Res 2003;47(4-5):231-7.

https://doi.org/10.1046/j.1365-2788.2003.00485.x.

11. Ranogajec A. Znanje i Stavovi Opće Populacije Osječko-baranjske Županije o Osobama s Posebnim Potrebama. Završni Rad. Bjelovar: Visoka Tehnička Škola u Bjelovaru; 2017.

12. Dobrotić I, Pećnik N, Baran J. Potrebe Roditelja i Pružanje Usluga Roditeljima Koji Podižu Djecu u Otežanim Okolnostima. Zagreb: Udruga Roditelji u Akciji; 2015.

13. Glinac A, Matović L, Delalić A, Mešalić L. Quality of life in mothers of children with cerebral palsy. 2017;56(2):299-307.

https://doi.org/10.13112/pc.2016.1.

14. Cvitković $D$, Ralić AZ, Wagner JA. Vrijednosti, interakcija sa zajednicom i kvaliteta života obitelji djece s teškoćama u razvoju. Hrvatska Rev Rehabil Istraživanja 2013;49:10-22.

15. Houtrow A. Preventive Health Care for Children with and Without Special Health Care Needs. Department of Pediatrics. California: University of California at San Francisco; 2008

16. Išpanović V. Psihomotorni i Psihosocijalni Razvoj u Detinjstvu. Primarna Zdravstvena Zaštita Majke i Deteta. Priručnik za Obrazovanje Zdravstvenih Radnika u Primarnoj Zdravstvenoj Zaštiti. Institut za Zdravstvenu Zaštitu Majke i Deteta Srbije. Beograd: Čigoja Štampa; 1976. p. 78-86. https://doi.org/10.5937/zz1604031z.

17. Bergner M, Bobbit R, Carter W, Gilson B. The sickness impact profile: Development and final revision of a health status measure. Med Care 1981;8:787-805.

https://doi.org/10.1097/00005650-198108000-00001

18. The WHOQOL Group. Development of the World Health Organization WHOQOL-BREF quality of life assessment. Psychol Med 1998;28(3):551-8. https://doi.org/10.1017/s0033291798006667.

19. Golubić R. Domene Kvalitete Života kao Prediktori Radne Sposobnosti Bolničkih Zdravstvenih Djelatnika. Doktorska Disertacija. Zagreb: Medicinski Fakultet, Sveučilište u Zagrebu; 2010 https://doi.org/10.15255/kui.2018.026.

20. Vuletić G. Kvalitet Života i Zdravlje. Osijek: Hrvatska Zaklada za Znanost; 2011. p. 9-11.

21. Pibernik-Okanovic M. Psychometric properties of the World Health Organisation quality of life questionnaire (WHOQOL-100) in diabetic patients in Croatia. Diabetes Res Clin Pract 2001;51(2):133-43.

https://doi.org/10.1016/s0168-8227(00)00230-8.

22. Taderera $\mathrm{C}, \mathrm{Hall} \mathrm{H}$. Challenges faced by parents of children with learning disabilities in Opuwo, Namibia. Afr J Disabil 2017;6:283.

https://doi.org/10.4102/ajod.v6i0.283.

23. Cuskelly M, Hauser-Cram P, Van Riper M. Families of Children with Down Syndrome: What we know and what we need to know. Down Syndrome Research and Practice; 2008. Available from: https:/l www.assets.cdn.down-syndrome.org/pubs/a/reviews-2079.pdf? ga $=2.52320873 .1112036347 .1564132787-1040626289.1564132787$. [Last accessed on 2019 Jul 01].

https://doi.org/10.1037/e496622004-001.

24. Hawthorne G, Herrman H, Murphy B. Interpreting the WHOQOLBrèf: Preliminary population norms and effect sizes. Soc Indic Res 2006;77:37-59

https://doi.org/10.1007/s11205-005-5552-1.

25. Wu J, Zhang J, Hong Y. Quality of life of primary caregivers of children with cerebral palsy: a comparison between mother and grandmother caregivers in Anhui province of China. Child Care Health Dev 2017;43(5):718-24. https://doi.org/10.1111/cch.12464. 
26. Lee MH, Matthews AK, Park C. Determinants of health-related quality of life among mothers of children with cerebral palsy. J Pediatr Nurs 2019;44:1-8. https://doi.org/10.1016/j.pedn.2018.10.001.

27. Sljivo E, Rudic A, Jusupovic F. Quality of life as a predictor of work ability of employees of Sarajevo tobacco factory. J Health Sci 2016:6(1):52-8. https://doi.org/10.17532/jhsci.2016.344.

28. Barros AL, de Gutierrez GM, Barros AO, Santos MT. Quality of life and burden of caregivers of children and adolescents with disabilities. Spec Care Dentist 2019;39(4):380-8.
29. Steel R. Family quality of life in 25 Belgian families: Quantitative and qualitative exploration of social and professional support domains. J Intellect Disabil Res 2011;55(12):1123-35.

https://doi.org/10.1111/j.1365-2788.2011.01433.x.

30. Kuru N, Piyal B. Perceived social support and quality of life of parents of children with Autism. Niger J Clin Pract 2018;21(9):1182-9.

31. Švraka E, Avdić D, i sar. Naša vizija budućnosti: Inkluzija osoba s cerebralnom paralizom i inaktivitetna osteoporoza, Sarajevo: Savez udruženja osoba s cerebralnom paralizom $\mathrm{FBiH}, 2015$; 59-64 